\title{
Corporate Social Responsibility as a Practicality of Ubuntu to Build Brand Loyalty: A Case of Mobile Telecommunication in South Africa
}

\author{
Belinda Senooane \\ Lecturer, Durban University of Technology \\ belindad@dut.ac.za
}

\author{
Doi:10.5901/mjss.2014.v5n25p167
}

\begin{abstract}
This study contributes to an understanding of corporate social responsibility (CSR) as a tool that can be used to build brand loyalty within the framework of Ubuntu. Despite intermittent research illustrating the importance of CSR within an African context, there is a knowledge gap with regards to how CSR can be implemented from a humanist perspective which values 'supportiveness, cooperation and communism' and how this can be used to foster loyalty amongst consumers. The purpose of the paper is to operationalise CSR as an application of Ubuntu rather than as a western business tool. Insights are drawn from a quantitative survey that included 246 customers of the South African mobile service provider Vodacom. The findings revealed that most consumers believe that companies are morally obligated to be socially responsible. Furthermore, it was determined that customers view organizations as being part of society and are therefore obligated to contribute as humans would. Drawing from the findings, it is recommended that companies need to take a more proactive approach to CSR and position it within the Ubuntu framework. Implications for managers and future research directions are also discussed.
\end{abstract}

Keywords: Ubuntu, corporate social responsibility, corporate citizenship, brand image, brand loyalty

\section{Introduction}

Societal expectations about the positive contributions from corporations are not a new phenomenon as the history of CSR dates back many centuries (Aguinis \& Glavas, 2012). The industrial revolution, which gave corporations great power and immense wealth (Connolly and Prothero, 2008) also brought about the growth in the realisation that with great power comes great responsibility (Crane, Matten \& Spence, 2008). Within this context, corporations were required to operate more ethically and many felt that they were morally obligated to see to the development of the societies that were giving them this power. In recent decades, corporate social responsibility has continued to grow in importance and significance. This has been fuelled largely by global environmental concerns, poverty in $3^{\text {rd }}$ world countries as well as well publicised scandals involving major international organisations (Carroll \& Shabana, 2010). In this regard, CSR has largely been operationalised as a western business tool that can be used as an organisational strategy to gain competitive advantage and obtain social capital (Burchell \& Cook, 2006). However the use of CSR as a business strategy has always been frowned upon by consumers. An example of this is evidenced by the harsh criticism that the tobacco company Philip Morris received after they spent $\$ 75$ million on philanthropic activities, and then publicized them in a $\$ 100$ million advertising campaign (Palazzo \& Ritcher, 2005; Hseih \& Lee, 2008). In response to this criticism we propose an alternative positioning of CSR activities by organizations. Within the African context, the concept of Ubuntu, which is used to define "humanness" and "personhood" has come to be accepted as a standard of what it means to be African (Bennett, 2011). Generally, Ubuntu has been associated with concepts such as humanness, interconnectedness and concern for others which seem to be consistent with CSR values internationally (Kayuni \& Tambulasi, 2012). Embedded within the concept of CSR, is an understanding that power should be used fairly; a moral duty to promote social justice, and a commitment to control and legitimizes business operations. This study seeks to test this relationship empirically. The study argues that CSR initiatives of firms be positioned within this framework in order to foster brand loyalty. We argue that organisations are 'corporate citizens' that are expected to adhere to the social principles of the societies in which they exist. The key objectives of the paper are to determine consumer attitudes towards specific CSR programs when positioned within the Ubuntu framework as well as determine the impact of said CSR on brand loyalty. To this end, we take a quantitative approach to investigate the specific role of CSR within the South African context, and how this is used as a strategic intangible resource in building brands. While seeking to contribute to existing knowledge beyond the South African context, we employ a survey approach in the area of Pietermaritzburg in South Africa. 


\section{Literature Review}

\subsection{Ubuntu}

Ubuntu has been a difficult concept for scholars and researchers alike to define explicitly because of the many connotations and cultural implications that are associated with the term (Gade, 2011; Bennett, 2011). Critics of Ubuntu have termed it as nothing but an attempt to "package decision-making in the appearance of traditional African values" (Cornell \& Marle, 2005) while its proponents argue that it embodies the spirit of African values. The term was popularised in South Africa in the 1920s by the Zulu freedom movement Inkatha, when they used it as a slogan to revive love and respect for traditional Zulu values (Bennett, 2011). The term gained even wider spread popularity during the advent of democracy in South Africa where it was closely associated with the search for African dignity (Gade, 2011). Today Ubuntu is seen as social construct that attempts to define what "Africaness" means. According to Kayuni \& Tambalusi (2012) "it portrays interconnectedness where people are intrinsically interwoven within the social fabric". This definition sees people as being interdependent on each other and this reflecting in the way that society operates. The closest definition of this African culture is found in the Zulu proverb "umuntu ngumuntu ngabantu" roughly meaning "a person is a person through other persons" (Giddy, 2012). It is further defined as "capacity of 'African culture' (singular) to express compassion, reciprocity, dignity, harmony and humanity in the interests of building and maintaining a community with justice and mutual caring" (Tomaselli, 2009:583). In a Nelson Mandela Memorial lecturer in July 2006, then South African president Thabo Mbeki called upon citizens to "infuse the values of Ubuntu into [their] very being as a people" (Nkondo, 2007). He went on to describe how Ubuntu lies at the very core of our moral fibre and must be infused into the moral fabric of society. This highlighted the fact that even today in the $21^{\text {st }}$ century Ubuntu is still a necessary and integral part of society.

\subsection{Corporate Social Responsibility}

This research claims as a foundational premise that CSR matters in the everyday lives of organisations, and that this worthiness is often communicated through building brands that are associated with CSR elements. CSR is defined by the World Council for Sustainable Development as 'the continuing commitment by business to behave ethically and contribute to economic development while improving the quality of life of the workforce and their families as well as of the local community and society at large" (Crane, Matten \& Spence, 2008:6). CSR developed as a result of the interaction between industrialisation and globalisation (May, Cheney \& Roper, 2007). As industrialisation grew, corporations were criticised for advocating factory labour. The factory labour system required many work hours and that workers live far away from home thus it was having a negative impact on family and the community. To counter this criticism, corporations developed "industrial welfare programs... which provided for the education, recreation and socialisation" (May et al, 2007:4) of factory workers. Shortly after World War 1, Howard Bowen came up with what would become one of the earliest conceptions of CSR (May et al, 2007). He suggested at the time that "we are entering a time when private business will be judged solely in terms of its demonstrable contribution to general welfare" (May et al, 2007:5). As far as he was concerned, it was the responsibility of business to ensure better standards of living, economic growth, security and freedom. In the 1970s when corporations were reaping the highest benefits of industrialisation in America, the debate of CSR shifted from a focus on corporate responsibility to a one about corporate responsiveness (Steiner and Steiner 2009). The emphasis was no longer on business survival but rather on "political action, public affairs, lobbying, and public relations directed toward strategic philanthropy and cause related marketing" (Crane et al, 2007:5). At the turn of the century, corporate scandals of companies such as the Enron and Arthur Andersen in 2001 brought back issues of business ethics and corporate responsibility into sharp focus all over the world. The debate on corporate social responsibility intensified as companies abandoned morally responsible behaviour in order to satisfy their financial imperatives (Crane et al, 2007). It is through this intensified debate that companies are now called upon to display more responsible behaviour.

Carroll (1991) developed the corporate social responsibility pyramid which has become the standard model that is used to define an organisation's social responsibilities. According to the model, the first and foremost responsibility of firms is the economic one. This is considered to be the foundation upon which all other responsibilities lie (Crane et al, 2007). If the firm is able to perform financially then it is able to perform other duties as well. A firm that is performing well will not need to breach ethical or legal responsibilities by committing crime. Philanthropic responsibilities include all responsibilities that are not expected in a moral or ethical sense but rather those that are a company's reaction to society's expectations from them (Crane et al, 2008:64). This means that even though there are no statutes concerning 
how a firm should give back to society that firm will still be able to regulate itself into doing so.

Figure 1: The Corporate Social Responsibility Pyramid

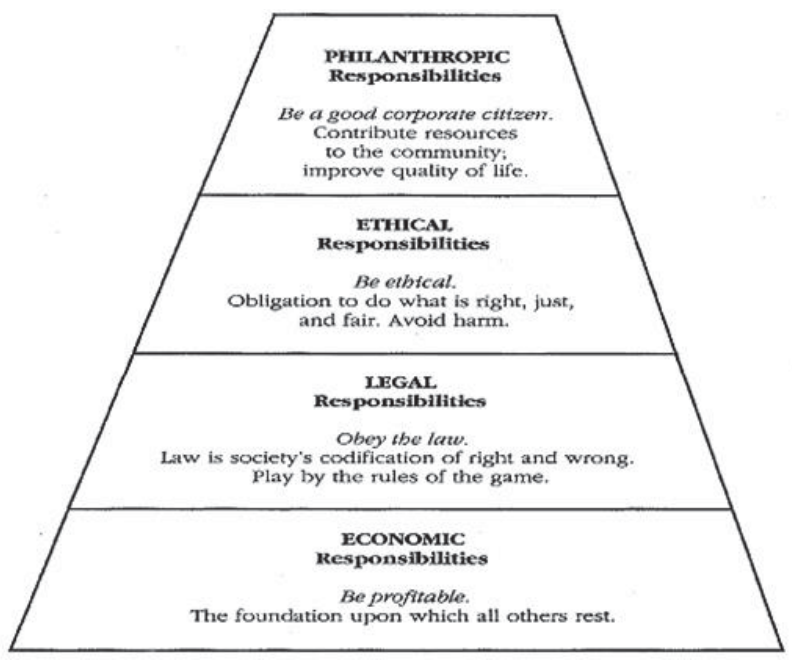

Source: Carroll, 1991:42

There are a variety of reasons why a business would want to be involved in CSR. These reasons are often influenced by the firm's products or services, the location of production facilities, the size of the firm, the macro environment in which that firm operates and most importantly the leadership of the firm (Hohnen \& Potts, 2007). Essentially, the main reason why firms may want to adopt CSR is that it can be used as a strategic approach to enhance corporate image by addressing issues stemming from their existence that are of importance to stakeholders and the society (Hohnen \& Potts, 2007). One of the ways of achieving this is that CSR can lead to the development of social capital. Social capital is the enduring belief by members of society that a corporate citizen such as a company has the right to operate because of the positive reputation that company has (Hohnen \& Potts, 2007). Consumers start to believe that an organisation has the right to operate due to the positive corporate image that they have. CSR can also lead to superior reputation management. The reputation of a company or the equity that is attached to that brand is based on the principles of trust, quality, reliability, credibility and consistency (Hohnen \& Potts, 2007).

\subsection{Corporate Citizenship}

CSR allows businesses to adopt the persona of corporate citizens through greater interacting with civil society (Burchell \& Cook). In order for a business to maintain its social capital, it must behave in a way that is socially responsible toward its customers (Burchell \& Cook, 2006). Social capital is the enduring belief by members of society that a corporate citizen such as a company has the right to operate because of the positive reputation that company has (Hohnen \& Potts, 2007) Businesses are considered to be a reflection of the people who run them who are in turn a reflection of the societies from which they come. In fact organisations are seen as microcosms of their immediate society (Kayuni \& Tambulasi, 2012). Companies can use CSR to develop strong links with the communities in which they operate as well as contribute to the relationship between capital and civil society.

\subsection{Ubuntu and Corporate Social Responsibility}

A person [or an organisation] with Ubuntu is welcoming, hospitable, warm and generous, willing to share. Such people [or organisations] are open and available to others, willing to be vulnerable, affirming of others, do not feel threatened that others are able and good, for they have a proper self-assurance that comes from knowing that they belong in a greater whole. They know that they are diminished when others are humiliated, diminished when others are oppressed, diminished when others are treated as if they were less than who they are. The quality of Ubuntu gives people [or organisations] resilience, enabling them to survive (Tutu 2005:26). 
While Ubuntu has been part of sociological discourse for decades, its use in management studies has steadily increased over the years (Bolden \& Kirk 2009;Kayuni \& Tambulasi, 2012). They argue that although there has been little done by way of empirical research to establish a relationship between the two, Ubuntu has wide spread implications for CSR as its practise can enhance the values of Ubuntu. Mallone \& Wilder (2008) argue that "we are all part of a universal humanity and should thus share universal concern for one another". By sharing this universal concern for others through CSR, corporations can reap the benefits aforementioned.

\subsection{Brand Loyalty}

Customer loyalty has been a predominant construct in services and marketing research (Chaudri \& Holbrook, 2001; Rowley, 2005; Soderlund, 2006). Loyalty is defined "as a deeply held commitment to re-buy or re-patronise a preferred product or service consistently in the future, thereby causing repetitive same brand set purchasing, despite situational influences and marketing efforts having the potential to cause switching behaviour" (Hseih \& Li, 2008:31). This means that even in extremely competitive markets, where markets are characterized by price cuts and positioning wars, consumers may be persuaded to remain with a product. If a company knows that there are certain consumers who will always buy their brand then they can at least be sure that they will be able to remain in business. Customer loyalty however is not easy to earn as consumers can be easily influenced by other companies. According to Rowley (2005:574) the primary benefits of customer loyalty include: lower customer price sensitivity, reduced expenditure on attracting new customers and improved organizational profitability. When consumers are loyal to a brand they may find it challenging to switch to another. Brand loyalty has been operationalized as consisting of purchase related or attitudinal loyalty (Chaudri \& Holbrook, 2001; Romanuick \& Nenycz-Thiel, 2013). Purchase related loyalty refers to how often the consumer buys that brand compared to that of the competition whilst attidudinal loyalty refers to the consumer's perceptions of being committed to the brand. Firms that want to get ahead in today's incredibly competitive world need to outperform competitors and maintain a competitive advantage over other firms so that consumers will always chose their brand even when faced with competing products (Sigalas \& Economou, 2013).

\section{Theoretical Framework and objective development}

The theoretical framework guiding this research is depicted in Figure 1 below. The research will study desired outcomes of CSR, namely brand trust, brand image and brand loyalty. In this model, corporate social responsibility positioned within the framework of Ubuntu will lead to the development of brand trust in the minds of consumers and the creation of a positive brand image. Positive brand associations and a positive brand image will in turn lead to customer loyalty.

Figure 2: Conceptual Model

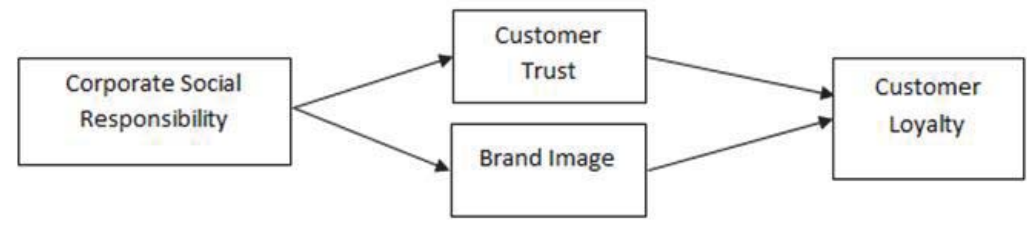

\subsection{Objective 1: CSR can lead to brand trust}

The concept of customer trust in this research is used as customer's belief in a brand manifested by their belief in the credibility of that brand. According to research by Barnes (2011) brand trust is a major and necessary component for loyalty as it means that customers have faith in the product they are buying. The relationship between customer trust and customer loyalty is yet to be strongly proven from a research standpoint as different researchers have come up with different results (Chinomona \& Dubihlela, 2014). The brand trust construct was measured using the 7 point Likert scale adopted from Chaudri \& Holbrook (2001) with scale points ranging from (1) Very Strongly Agree to (7) Very Strongly Disagree. The 4 items included in the scale were the 4 statements "I trust this brand", "I rely on this brand", "This is an honest brand" and "This brand is safe". 


\subsection{Objective 2: CSR has a direct influence on brand image}

Brand image refers to the sum total of consumer perceptions of a brand, as reflected by the several forms of brand associations they hold in memory concerning that brand (Keller, 2008). Positive interactions with a brand can lead to strong, favourable and unique brand association which can in turn lead to brand equity, which is the value associated with a brand (Keller, 2012). One of the primary sources of brand equity is brand image. According to Aaker (1991) brand image helps to differentiate a brand, provides consumers reason to buy the product and generate positive feelings for the brand thereby creating value for the brand. The brand image construct was measured with a 5 point Likert Scale with scale points labelled ranging from (1) Strongly Agree to (5) Strongly Disagree. The variables used were "Superiority to Competitors of CSR", "Positive perception of CSR advertising", "Vodacom Credibility", "I consider Vodacom a corporate citizen" and "I believe CSR has a positive influence on a company's image".

\subsection{Objective 3: Brand trust and brand image lead to customer loyalty}

The final objective for the study proposes that when brand trust and a positive brand image (determined from positive brand associations) are developed in the mind of the consumer they will lead to brand loyalty. The brand loyalty construct was measured using a 5 point Likert Scale adapted from Chaudri \& Holbrook (2001) with the 4 items "I intend to keep purchasing brand", "I would recommend this brand to others", "I am committed to this brand" and "I would not consider switching from this brand". The scale was rated from 1 "strongly agree" to 5 "strongly disagree".

\section{Research Methodology}

The primary data for the study was collected from a sample of Vodacom customers in Pietermaritzburg South Africa. The target population were customers who are patrons of the Vodacom Customer Care Centre at Liberty Midlands Mall. The respondents were selected based on their willingness to participate in the study. The purposive sampling method was used to select the respondents using two criteria: knowledge of the concept of corporate social responsibility and knowledge of at least 5 of the Vodacom CSR activities presented to respondents. The population was determined to be 3059. This figure was determined by multiplying the number of customers who visit the customer care centre per day (230-5\% repeat customers) by two weeks. From the population, a sample of 385 was determined using a sample size calculator with a confidence level of $95 \%$ and a confidence interval of 5 . Although the resultant number was not entirely representative of all Vodacom customers, it was relevant for the study given time and resource constraints. Due to incomplete or poorly completed questionnaires, 139 of the questionnaires could not be included in the data analysis therefore only 246 were included. The descriptive statistics of the participants are illustrated in table 1 below.

Table 1: Demographic Statistics

\begin{tabular}{ccccccccc} 
& Age & \multicolumn{3}{c}{ Gender } & \multicolumn{3}{c}{ Race } \\
\hline & Frequency & Valid $\%$ & & Frequency & Valid $\%$ & Frequency & Valid \% \\
$\mathbf{1 8 - 2 4}$ & 138 & 56.1 & Male & 111 & 45.1 & White & 24 & 9.8 \\
$\mathbf{2 5 - 3 0}$ & 47 & 19.1 & Female & 135 & 54.9 & African & 166 & 67.5 \\
$\mathbf{3 1 - 4 0}$ & $40 \mathrm{yy}$ & 16.3 & & & & Indian & 13 & 12.6 \\
$\mathbf{4 0 >}$ & 21 & 8.5 & & & Coloured & 25 & 10.2 \\
Total & 246 & 100.0 & Total & 246 & 100.0 & Total & 246 & 100.0
\end{tabular}

The data was collected using a self-administered questionnaire with research questions being descriptive in nature. The questionnaire was administered between June and August 2013. The questionnaire was administered to 10 respondents in a pilot study to ensure validity. Cronbach's Coefficient Alpha was used to analyse the reliability of the questionnaire and the results. Results of the reliability analysis reveal that with a number of 22 items in the questionnaire, the Cronbach Alpha value was .750 which is above 0.7 . Randomly selected Vodacom customers were used as the pilot test participants. This method of participant selection was justified in the sense that random selection was to be used for the official study. No incentives were offered to the respondents for their participation. 


\section{Results and Discussion}

\subsection{Ubuntu and CSR}

To measure respondents' understanding and perceptions of Ubuntu and CSR as well as their understanding of the relationship between the two, 5 statements were posed to respondents. All 246 of the respondents either strongly agreed $(97.2 \%)$ or agreed (2.8\%) that they had a good understanding of Ubuntu. Furthermore, $89.4 \%$ of the respondents felt that Ubuntu is a principle that should be applicable to business. This is consistent with the previously noted sentiments that consumers believe that companies should be held accountable in society like human beings would. Another important variable to note was that when asked to select which of the 4 responsibilities they believed were the most important, philanthropic responsibilities was selected by the highest number of respondents $(38.6 \%)$ while economic responsibilities were ranked second with $23.6 \%$ of respondents selecting it as the most important. This result is consistent with the primary argument of this study and contrary to the CSR pyramid which ranks economic responsibilities as being the most important. Critics of CSR have argued that it distracts from the fundamental economic role of business (Malai, 2011).

Table 2: Descriptive Statistics Ubuntu and CSR

\begin{tabular}{|l|c|c|c|c|c|}
\hline & N & Minimum & Maximum & Mean & Std. Deviation \\
\hline I have a good understanding of Ubuntu & 246 & 1.00 & 2.00 & 1.0285 & .16661 \\
Corporate Citizenship & 246 & 1.00 & 5.00 & 1.7073 & .89654 \\
Ubuntu Applicable to Business & 246 & 1.00 & 4.00 & 1.6423 & .76804 \\
CSR Awareness & 246 & 1.00 & 2.00 & 1.5935 & .49218 \\
CSR Obligation & 246 & 1.00 & 5.00 & 1.7480 & 1.01494 \\
Valid N (listwise) & 246 & & & & \\
\hline
\end{tabular}

According to the results from the study, respondents aware of what CSR is and 58\% of them believed that From the table above, the first 3 variables were measured on a Likert Scale valued from 1 "strongly agree" to 5 "strongly disagree". On all 3 variables, the mean was a value of less than 2 suggesting that respondents had a good understanding of Ubuntu as well as believing that companies were obligated to be corporate citizens. This result also means that there is a natural expectation by most people that a company be responsible. With a mean of 1.6, the results also suggest that the majority of respondents believed that the concept of Ubuntu is applicable to business. According to Crane, Matten \& Spence, 2007 , it is important for companies to perform in a manner consistent with expectations of society.

Table 3: Brand Image, Brand Trust and Brand Loyalty

\begin{tabular}{|l|c|c|c|c|c|}
\hline Variables & $\mathrm{N}$ & Minimum & Maximum & Mean & Std. Deviation \\
\hline I believe Vodacom is more socially responsible than competitors & 246 & 1.00 & 5.00 & 1.7154 & 1.19195 \\
I believe Vodacom is a responsible corporate citizen & 246 & 1.00 & 5.00 & 1.9756 & 1.02590 \\
I believe in Vodacom's CSR Advertising & 246 & 1.00 & 4.00 & 1.4472 & .77410 \\
I consider Vodacom to be a credible brand & 246 & 1.00 & 3.00 & 1.5732 & .51183 \\
Vodacom's CSR has a positive influence on how I view the brand & 246 & 1.00 & 5.00 & 2.2276 & 1.09778 \\
I trust this brand & 246 & 1.00 & 5.00 & 1.5569 & .92296 \\
I rely on this brand & 246 & 1.00 & 5.00 & 1.5447 & .95833 \\
This is an honest brand & 246 & 1.00 & 5.00 & 1.4553 & .81066 \\
This brand is safe & 246 & 1.00 & 4.00 & 1.1870 & .47552 \\
I intend to repurchase this brand & 246 & 1.00 & 4.00 & 1.7724 & .86012 \\
I would recommend this brand to others & 246 & 1.00 & 4.00 & 2.0732 & .68417 \\
I believe I am committed to this brand & 246 & 1.00 & 5.00 & 2.3333 & 1.10780 \\
I would not consider switching from this brand to another & 246 & 1.00 & 5.00 & 1.5854 & .90736 \\
Valid N (listwise) & 246 & & & & \\
\hline
\end{tabular}

Corporate social responsibility (CSR) is very much at the heart of contemporary marketing (Malai, 2011:166). CSR also plays a role in different marketing activities, and building powerful brands (Salmones et al 2005). The results of this study which measure some of these brand elements seem to support these arguments. The table above shows the descriptive statistics for the constructs brand image ( 5 variables), brand trust (4 variables) and brand loyalty ( 4 variables). For the 
brand image construct the first 4 variables yielded a mean value of less than 2, meaning that the majority of respondents either strongly agreed or agreed with the statements. The cumulative frequency values for either strongly agree or agree were: I believe Vodacom is more socially responsible than competitors (80.95), I believe Vodacom is a responsible corporate citizen (77.4\%), I believe in Vodacom's CSR Advertising (85\%), I consider Vodacom to be a credible brand $(99,2 \%)$ and Vodacom's CSR has a positive influence on how I view the brand (64.6\%). These results imply that consumers generally have a positive brand image.

Brand trust was included as one of the measurement of loyalty because researchers have argued that it can influence repurchase decisions (Jarvenpaa, Tractinsky, \& Vitale, 2000). For the brand trust construct, all the variables yielded a mean value of less than 2 meaning that the majority of respondents either very strongly agreed with the statements or they strongly agreed. The cumulative frequency values for both scales were: I trust this brand (88.6\%) I rely on this brand (88.2\%), This is an honest brand (89\%) and This brand is safe (97\%). with more than $85 \%$ of the respondents answering in the affirmative for all the variables in the brand trust construct, the results suggest that consumers have very high levels of trust for this brand. These results were consistent with the findings of Kim \& Han (2008) who determined that trust has a positive influence on customer loyalty in the services industry.

For the brand loyalty construct, which was the independent variable of the study, 4 variables were used to measure consumer attitudes. 2 of the variables yielded a mean value of less than whilst the other 2 yielded a mean value slightly above 2. This suggests that the majority of respondents responded in the affirmative [strongly agree or agree] when posed with questions regarding their loyalty to Vodacom. The cumulative frequencies for all the variables were as follows: I intend to repurchase this brand (77.2\%), I would recommend this brand to others $(74.4 \%)$, I believe I am committed to this brand (59.8\%) and I would not consider switching from this brand to another (99.1\%). These results suggest that the majority of respondents consider themselves as being loyal to the brand. A notable result here is that only $59.8 \%$ of the respondents said that they believed they were committed to the brand yet almost all (99\%) of the respondents said that they would not consider switching. Researchers have determined that loyalty is predicated on both attitudinal loyalty and purchase intentions (Chaudri \& Holbrook, 2001; Mandhachitara \& Poolthong, 2011). Furthermore, Uncles \& Dowling (2003) notes that many researchers have argued that for true loyalty to exist, there must a strong sense of attitudinal loyalty.

\section{Conclusions}

Companies may wish to express their commitment to the communities, and environments in which they do business, through aligning their brands with motives other than financial gains. Yet, when confronted with tough economic times, these companies may opt to focus on maximising their financial returns, as evidenced by the economic downturn that faced many countries in 2007, 2008, and 2009. This is consistent with previous research that has argued that a firm's sole responsibility is to provide maximum financial returns to its shareholders (Steiner and Steiner, 2009). However, in this paper we have attempted to demonstrate that corporate social responsibility has a positive impact on consumer perceptions and on brand loyalty when positioned within the framework of Ubuntu and can used to support the achievement of economic objectives rather than disrupt the. In this context brand loyalty is measured as a result of brand trust and positive brand image which are themselves the result of a corporate citizen being socially conscious. This study supports the view that CSR should be operationalised in an African context from a perspective of Ubuntu rather than as a western business tool to gain economic advantages.

\section{Managerial implications}

- Corporations need to take a proactive rather than a reactive approach to corporate social responsibility. Corporations need not only be responsive to social issues as they arise but rather seek to be socially conscious at all times. Corporations that are known to be socially responsible are more likely to gain the trust and credibility necessary brand loyalty.

- Increase consumer engagement. By implication, corporations need to engage all the relevant stakeholders in terms of what they feel will be appropriate CSR activities. What the corporation may consider to be socially responsible behaviour may be seen as stakeholders, especially investors as a waste of company resources.

- Report on CSR achievements rather than advertise them. Consumers react negatively to CSR that is advertised for publicity therefore managers need to determine how they will bring their activities to the attention of their stakeholders.

- Adopt a focused CSR Approach. One of the main criticisms that consumers had of Vodacom CSR is that they 
were involved in a large number of CSR activities. Firms in this case are encouraged to choose fewer causes to support but provide as much support as they can.

\section{Limitations and Suggestions Future Research}

The study was limited to Pietermaritzburg, South Africa. Future research can be conducted that includes other provinces in South Africa as well as other African countries. A comparative study between countries can analyse how CSR is applied within the Ubuntu framework and attempt to identify the differences and commonalities between and across societies. Furthermore, the study only included 246 respondents therefore the results cannot be generalised. Another limitation is that the study was conducted with only one company. Including more companies from different industries would provide more holistic and insightful results. Different industries may have different ways of implementing their CSR which in itself can lead to their customers having different views on what constitutes socially responsible behaviour. Lastly, further empirical testing of the research model is needed in order to statistically support the model and refine the model components.

\section{References}

Aaker, D.A. (1991). Managing Brand Equity. New York: Free Press.

Aguinis, H. \& Glavas, A. (2012). What We Know and Don't Know About Corporate Social Responsibility: A Review and Research Agenda. Journal of Management, 38 (4), 932-968.

Barnes, A,J. (2011). Corporate Social Responsibility and its effects on brand trust. Master's Thesis.

Bennett, T.W. (2011). Ubuntu: AN African Equity. Potchefstroom Electronic Law Journal, 14 (4), 30-61.

Bolden, R. \& Kirk, P. (2009), "Development African leadership: surfacing new understandings through leadership", International Journal of Cross Cultural Management, 9 (1), 69-86.

Burchell, J. \& Cook, J. (2006). Confronting the "corporate citizen" Shaping the discourse of corporate social responsibility, 26 (3), 121137.

Carroll, A.B. \& Buchholtz, A.K. (2008). Business and Society: Ethics and Stakeholder Management. USA: Cengage Learning.

Carroll, A. B. \& Shabana, K. M. (2010). The Business Case for Corporate Social Responsibility: A Review of Concepts, Research and Practice. International Journal of Management Reviews, 12, 85-105.

Caruana, A. (1997). Corporate Reputation: Concept and measurement. Journal of product and brand management, 6 (2),109 - 118.

Chaudhuri, A. \& Holbrook, M.B. (2001). The Chain Effects from Brand Trust and Brand Affect To Brand Performance: The Role Of Brand Loyalty. Journal of Marketing. 65 (2), 81-93.

Cornell, D. \& van Marle, K. (2005). African Human Rights Law Journal, 5 (2), 195-220.

Connolly, J. \& Prothero, A. (2008). Green Consumption Life-politics, risk and contradictions. Journal of Consumer Culture, 8(1), 117145.

Crane, A., Matten, D. \& Spence, L, J. (2008). Corporate Social Responsibility: Readings in a global context. New York: Routledge.

Department of International Relations. (2006). Nelson Mandela Memorial Lecture by President Thabo Mbeki. Retrieved 22 July 2014 from http://www.daf.gov.za/docs/speeches/2006/mbek0729.htm.

Esty, D. \& Winston, A. (2006). Green to Gold: How smart companies use environmental strategies to innovate, create value, and build competitive advantage. International Chamber of Commerce.

Gade, C.B.N. (2011). The Historical Development of the written Discourses on Ubuntu. South African Journal of Philosophy, 30 (3), 303329.

Giddy, P. (2012). "Philosophy for Children" in Africa: developing a framework. South African Journal of Education, 32, 12-25.

Griffin, J., (2002). Customer Loyalty: How to Earn It, How to Keep It, New and Revised Edition, Weekly publisher.

Healy, P.M. \& Palepu, K.G. (2003). The fall of Enron. Journal of Economic Perspectives, 17 (2), pp. 3-26.

Hohnen, P. \& Potts, J. (2007). Corporate Social Responsibility: An Implementation Guide for Business.: http://www.iisd.org/pdf/2007/ CSr_guide.pdf .

Hsieh, A.T. \& Li, C.A. (2008). The moderating effect of brand Image on public relations perception and customer loyalty. Marketing Intelligence and Planning, 26 (1), 26-42.

Jarvenpaa, S. L., Tractinsky, J. \& Vitale, M. (2000). Consumer trust in an internet store. Information Technology and Management, 1(1\&2), 45-71.

Kayuni, H.M. \& Tambulasi, R.I.C. (2012). Ubuntu and corporate social responsibility: the case of selected Malawian organizations. African Journal of Economic and Management Studies, 3 (1), 64-76.

Keller, K.L. (2008). Strategic Brand Management: Building, measuring and Managing Brand Equity. Upper Saddle River: Pearson Prentice Hall.

Malai, V. (2011). The effects of corporate social responsibility on customer loyalty. Review of Business Research. 11 (2), 166-169.

Malone, T. and Wilder, W. (2008). Chasing Ubuntu: using ICTs to promote reflective practice. Multicultural Education \& Technology Journal, 2 (2), 118-25. 
Mandhachitara, R. \& Poolthong, Y. (2011). A model of customer loyalty and corporate social responsibility. Journal of Services Marketing, 25 (2), 122-133.

May, S., Cheney, G. \& Roper, J. (2007). The Debate over Corporate Social Responsibility. USA: Oxford University Press.

Michael, S. C. \& Pearce, J. A. (2006). Strategies to prevent economic recessions from causing business failure. Business Horizons, 49, 201-209.

Owen, D. (2005). CSR after Enron: A Role for the Academic Accounting Profession? European Accounting Review, 14 (2), $395-404$.

Palazzo,G. \& Richter, U. (2005). CSR Business as Usual? The Case of the Tobacco Industry. Journal of Business Ethics, 61 (4), p387401.

Patel, A.M. (2013). Corporate Social Responsibility. Golden Research Thoughts, 2 (12), 2-9.

Porter, M. E. \& Kramer, M.R. (2007). Strategy and Society: The link between Competitive Advantage and Corporate Social Responsibility. Harvard Business Review, 1-13.

Rowley, J. (2005). The 4 Cs of Customer Loyalty. Marketing Intelligence \& Planning, 23 (6), 574-581.

Romanuick, J. \& Nenycz-Thiel, M. (2013). Behavioral brand loyalty and consumer brand associations. Journal of Business Research, 66 (1), 67-72.

Salmones, M., Herrero Crespo, A. \& Rodriguez Del Basque, I. (2005). Influence of Corporate Social Responsibility on Loyalty and Valuation of Services. Journal of Business Ethics, 61 (1), 369-385.

Sigalas, C., Economou, V.P. (2013), "Revisiting the concept of competitive advantage. Problems and fallacies arising from its conceptualization", Journal of Strategy and Management, 6 (1), 61-80.

Söderlund, M. (2006). Measuring customer loyalty with multi-item scales: A case for caution. International Journal of Service Industry Management, 17 (1), $76-98$.

Tomaselli, K. (2009), "Afri(ethics), communitarianism and libertarianism", International Communication Gazette, 71 (7), $577-94$.

Tutu, D. (2005), God Has a Dream. New York, NY: Doubleday.

Uncles, M.D. and Dowling, G. (2003). Customer loyalty and customer loyalty programs. Journal of Consumer Marketing, (20) 4, $294-316$. Van Den Inde, L. (2004). Corporate Responsibility in South Africa, fact or fiction? Rand Afrikaans University.

Wellman, C, Kruger, F \& Mitchell, B. (2005). Research methodology. 3rd Edition. Cape Town: University Press. 